\title{
Evaluation of Learning Objects from the User's Perspective: The Case of the EURIDICE Service
}

\author{
Elena Maceviciute and T. D. Wilson \\ University College of Borås, Borås, Sweden
}

elena.maceviciute@hb.se tom.wilson@hb.se

\begin{abstract}
We describe a project to evaluate an image database within an educational context. The partners in the EURIDICE project were educational institutions in a number of countries, together with other agencies and one commercial partner. Input to the database was provided by the commercial partner, a public library, and state archives. Evaluation was guided through a workshop in which all institutions participated to ensure comparability of data across the Project. Specific attention was paid to the needs of sight impaired students. The results indicated that the image database was considered to be of value for teaching and learning, but required further work to make it a fully viable system. In particular, the scope of the database needed to be expanded and the retrieval mechanisms improved.
\end{abstract}

Keywords: learning objects, evaluation, EURIDICE, information users, image database

\section{Introduction - The EURIDICE Project}

EURIDICE was a European project funded under the eTen programme which involved partners from seven countries. The project ran from 2005 to 2007 and involved the market validation of an image library for educational purposes composed of two sets of images: a set of images provided from the Alinari Fratelli digital photography library (the oldest photographic library in the world) and images from Polish archives and libraries. These image libraries were integrated through an e-learning platform, Galatea, provided and managed by the University of Leuven. The target market was higher education in the fields of humanities and social sciences, a somewhat unusual market from this perspective, since other photographic archives in education have tended to address the medical and scientific areas.

The 'Euridice service' consisted of access to the image databases through the Galatea platform, courses provided by the educational partners, which employed the images as a demonstration of potential, on a variety of e-learning platforms including Galatea, Moodle, ATutor, and others used in the partner institutions.

The partners were Fratelli Alinari S.p.A (Italy), International Center for Information Management System - ICIMSS (Poland), Torun Library (Poland), Krakow University (Poland), Leuven Uni-

Material published as part of this publication, either on-line or in print, is copyrighted by the Informing Science Institute.

Permission to make digital or paper copy of part or all of these works for personal or classroom use is granted without fee provided that the copies are not made or distributed for profit or commercial advantage AND that copies 1) bear this notice in full and 2) give the full citation on the first page. It is permissible to abstract these works so long as credit is given. To copy in all other cases or to republish or to post on a server or to redistribute to lists requires specific permission and payment of a fee. Contact Publisher@InformingScience.org to request redistribution permission. versity (Belgium), Barcelona Virtual University (UVB), Boras University (Sweden), Vienna University (Austria) and e-ISOTIS (Greece). The educational partners' function was to evaluate the users' response to the availability of an image database in course preparation and delivery. 
Access to e-learning platforms has opened up significant opportunities for blind and visuallyimpaired persons, in that they are able to access courses independently. e-ISOTIS involved people who were blind or who had reduced vision and, therefore, it was possible to evaluate the learning object from their perspective - especially important in terms of the images employed in the learning object.

The University College of Borås was the Swedish partner and was responsible, in addition to running a pilot implementation, for the evaluation of the 'EURIDICE service'. The evaluation process involved a training workshop on interviewing and focus group techniques for all the partner organizations and the development of interview schedules, questionnaires, and focus group guides, which were implemented locally by the partners.

\section{The Concept of 'Learning Object'}

We define a learning object as "Any entity, digital or non-digital, that may be used for learning, education or training" (Institute of Electrical and Electronic Engineers [IEEE], 2002). Thus, a book may be considered as a learning object if it is specifically intended to be used for educational purposes, or a search engine, used similarly, may also be considered a learning object. Generally, however, within the field of e-learning (within which the concept has arisen) the term refers mainly to digital objects. For example, Robert J. Beck (2007) of the Center for International Education at the University of Wisconsin-Milwaukee has created a Website devoted to learning objects (http://www.uwm.edu/Dept/CIE/AOP/learningobjects.html), and several of his examples are useful in understanding the concept. He cites the CNN interactive maps on the impact of the Cold War on political boundaries as a learning object of value in global studies. Another example, this time from Europe, is the ARIADNE Knowledge Pool System, which was developed with the intention of sharing multilingual teaching resources within Europe (http://tinyurl.com/27a29n).

Much of the learning objects literature is concerned with the structured creation of digital learning objects and deals with the employment of various tools, such as object-oriented programming languages (see e.g., McGreal, 2004). In that volume, Duval and Hodgins 'revisit' learning objects and comment in a way that reflects this concern with digitised learning objects:

'...we want to investigate

a taxonomy of LOs and their components,

a component architecture for structuring composite LOs and enabling their components to interact;

the process of aggregation and disassembly to produce new or repurpose existing LOs; and determinants for the efficiency and effectiveness of LO repurposing, and how these can be influenced by appropriate design methodologies (Duval \& Hodgins, 2004, p. 71).

However, the idea of learning objects is not without its critics; for example, in the same volume, Friesen identifies three problems with the concept. First, the definition we have quoted above, which is similar to many others, is too broad to be useful, since under this definition anything may be a learning object. Secondly, those involved in the production of standards for e-learning adopt a position of neutrality towards the pedagogic process and Friesen asks how a learning object can be dissociated from the process of learning in this way. Thirdly, the mechanistic systems modeling involved in the systematic production of learning objects is far from the messy, real life, social nature of the educational process. He concludes:

These techniques and processes may work well for more exclusively technical applications, but they are proving inadequate for dealing with the ambiguities implied in education and 
even in the deceptively simple term "learning." They also bring with them a culture and set of connotations that are (at the very least) not entirely helpful in public education. Perhaps most importantly for e-learning content and standardization, it is important to recognize that objects and infrastructures for learning cannot simultaneously be both pedagogically neutral and pedagogically valuable. Developers and designers will have to recognize and choose relevant (and probably differing) pedagogical positions, or risk pedagogical irrelevance. (Friesen, 2004, p. 66)

We do not wish to enter this argument in this paper, but we cite these concerns since the process of evaluation we will describe is designed to consider the use of a specific set of learning objects in the context of pedagogic issues in higher education.

\section{The EURIDICE Learning Objects}

The learning object of EURIDICE, that is the database, consisted of three 'libraries' of images: first (and largest), c. 5,000 images from the Alinari photographic library, consisting mainly of older ones from the 19th century and early 20th century across a wide variety of subject areas from social life to art objects; secondly, the National Archives of Poland provided 3,000 scanned historical documents from the regional historical archives of Poland including images relating to the history of Poland and other European states and nations from ancient to present times; finally, the Nicolaus Copernicus Library in Torun (the public library) provided approximately 2000 images of the front pages of old prints from the 16th and 17th centuries, printed in the largest towns of the Pomerania region and a variety of images of Torun's architecture from the Middle Ages to the present. In total, there were approximately 10,000 images in the collection, an example of which (from the Alinari collection), together with the description, is shown in Figure 1.

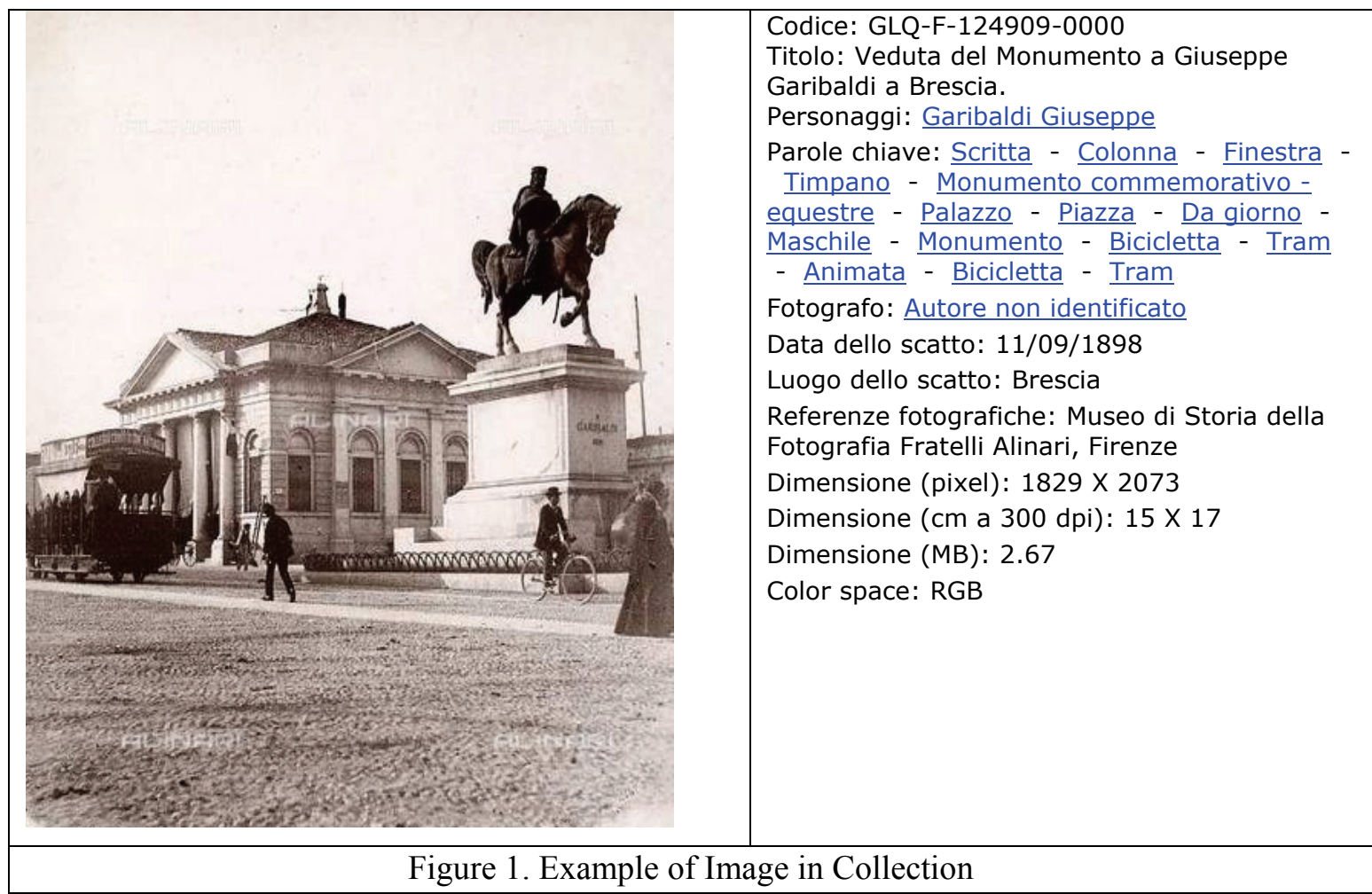


The database was supported by a multi-lingual search engine, which searched on the image descriptions in the database and provided thumbnail images for zooming and selection. The user of the database was able to construct, galleries'of images by searching for and selecting images for use in a particular course or lecture.

\section{Previous Research on Image Use in E-Learning}

Visual aids of one kind or another have long been used in education: teachers of art, anthropology, geography, medicine, biology, zoology, and other subjects have been accustomed to using diagrams, illustrations, maps, etc. in their teaching. Maintaining image quality, however, has always been a problem; for example, photocopying degrades images and physical image objects can be over-used and become useless in time. High-definition digital images, therefore, are of considerable potential value in education for projection and examination on-screen.

How to acquire images for educational purposes is problematical. There are costs in the digitisation process and, in an educational institution, issues of how the images are to be produced, catalogued, and stored-and by whom (Standford, 2002). There is also an issue of content: if teachers attempt to convert their own images, the process is time-consuming and may not result in the best possible digitization; see, for example Lecher (2004) on this. Images (of variable quality) can also be retrieved from the Internet but copyright issues have to be dealt with. Teachers may also experience software and hardware problems in downloading, processing, re-sizing, etc.

Consequently, the existence of digital libraries of images can be a boon to the teacher who sees images as something more than simply a means of making teaching materials more attractive. Images are 'information-rich' and, in many cases, can make apparent aspects of phenomena that verbal accounts cannot fully reveal. Mowat (2002) stated that images may enhance a presentation. They attract the student's attention and engage the learner by using thought-provoking images. The existence of images, sounds, and texts stimulate different areas of the brain and make learning a more active process, inspiring enhanced learning.

Mowat (2002) notes that if images are accessed by students they can be used in projects and other course work. Accessing images directly supports various kinds of activities such as organizing, analysing and comparing images, which may be an aid to learning and understanding. The enjoyment of learning affects how quickly people learn.

Besser (1999) reports on a study on the costs and uses of digital images at the University of California, Berkeley, in which faculty were interviewed in focus groups to identify important issues for the adoption of digital images in teaching and learning. Image quality, technical support and training, tools (software and hardware), and metadata were regarded as major factors in acceptance.

A study by Choi and Rasmussen (2002) on users' relevance criteria in image retrieval confirmed that the topicality (or content of the image) is the most important factor for searching images. The title and descriptors were used as "interpreters of image content and meaning" (p. 717). Searches for images according to title, date, and other features were also used to find relevant images. In addition, image quality and clarity were important. This research was also important in developing an assessment methodology.

\section{Evaluation of Learning Objects}

The issues of relevance in user-evaluation are: the appropriateness of the content to users' needs; the suitability of the image indexing; the capabilities of the search engine; customer evaluation (i.e., the perspective of the institution as a potential purchaser of services); and user computer interaction, that is, the navigation and other interface issues. 


\section{Evaluation from the Point of View of a Customer: Technical Validation}

From the customer's point of view the main issue is the compatibility of the EURIDICE service with the e-learning platforms and other means and tools used by the customer. This aspect of the service was decided by the partners (during the project period) and potentially by the future customers. The main source of this evaluation is based on the assessment of information and technical specification provided by Alinari (unpublished).

\section{Content}

The content of the learning object is intended to be used by students from a variety of disciplines and, consequently, may have greater or lesser value depending upon the nature of the discipline. For example, courses in the area of cultural heritage may have more critical users than those in fields such as library and information science. In one area the images may be of genuine research interest, while in another they may simply serve as exemplars of one kind or another, or may simply illustrate a historical point. Consequently, a 'scientific' analysis of the usefulness of the resource base from some set of objective criteria is not possible; the resources will be put to different uses and the key question will be, "How useful are the resources for the particular purpose intended?" In the evaluation a series of questions was developed, in association with the partners, to evaluate the content from the perspective of the courses they offered.

\section{Search Engine, Indexing, etc.}

A full evaluation of the retrieval performance of the search engine and its associated features was not intended; therefore, no attempt was made to determine precision and recall data for the purpose of comparing this search engine with others that are generally available. Instead, the intention was to evaluate the user's perception of performance. This required attention to a number of subsidiary issues:

Image indexing: Are the indexing terms associated with the images appropriate for the search intentions of the users?

Search capabilities: Are the search capabilities of the search engine presented effectively and are they fully utilised by the user? Which, if any, search features are under-used or not used at all, and why?

Response speed: Is the speed of response from an enquiry perceived to be adequate?

Presentation of results: Is the presentation of the search results helpful? If not, what style of presentation would users prefer? Does the user understand the criterion by which the images are ordered in the response? Is this criterion the most useful?

Satisfaction: Do the images provided in response to an enquiry satisfy the needs represented by the enquiry?

These issues were explored through formal interviews with the users, as the user was engaged in search activity, so that how the search engine was used could be observed as well as reported.

\section{Interface}

A full usability study of interface issues was beyond the capacity of the project, but two main issues were dealt with under this heading. First, the general clarity of the interface to guide the user to the available features of the system and the scope of the collection(s); and secondly, the ease of use of the navigation features provided. 
Interface usability: Ease of use of the interface is associated with factors such as the number and variety of features on the interface, the ease with which specific features (such as the search button) can be identified and the disposition of features on the page (their location, prominence, etc.). In the case of visually handicapped users there are additional issues such as the 'readability' of the screen by the relevant voice conversion software. Questions on these issues were devised in association with the partners and the system developers and were used in face-to-face interviews while students were using the system.

Navigation: There is no general practice for Website navigation, but certain conventions exist. For example, 'back' and 'forward' functions are generally shown by left and right pointing arrows and 'home' is usually shown as a button with a small house. Some sites adopt the conventions of the tape or video recorder, with buttons showing analogous functions to 'fast rewind' and 'fast forward', interpreted in Web systems as 'go to the start' and 'go to the end'. The over-riding principles of navigation are that, a) the mode of navigation should be consistent throughout the site; b) the location of the navigation features (in a navigation bar, or otherwise disposed) should be consistent on every page of the site; and c) the symbols used should be intuitively understandable (for a multi-lingual user audience this is a key requirement). The images involved should also have appropriate 'alt' descriptions for screen reader software to interpret to blind and visually-impaired persons.

From the point of view of user evaluation, therefore, the key questions relate to whether the user can easily identify the location of the navigation features; whether they are able to interpret the symbols readily, and whether they find the navigation features used consistently.

\section{The Outcome of EURIDICE Evaluation}

Both students and teachers were involved in the evaluation process: the students as the ultimate end-users of the courses that incorporated images and the teachers as involved in course design and development. The distribution of students over the pilot sites and courses is shown in the table in the Appendix. The majority of the teachers who used the service and were interviewed work at the departments of Library and Information Science of Borås University, University of Vienna, and Jagiellonian University. Others represented teachers of textile design, education and behavioural sciences, etc. Most of the teachers had significant experience in teaching from four to over 30 years. All in all 28 teachers and 10 course designers participated in the assessment (see the Appendix for details).

The students interviewed in the evaluation stage of EURIDICE were taking undergraduate and graduate programmes and were between 20 and 30 years of age. The younger students displayed higher confidence in technology use than the older ones, but the general level of computer abilities was quite high. Highest competency was shown in using e-mail and the Internet and lowest in the use of database creation software. Students had accessed the service on average between one and two times (access was limited because of delays in providing the service and the end of the academic year). The duration of a session was from 10 to 45 minutes and was related to how often the site was accessed-duration reduced with the number of instances of access.

\section{Content and Scope of the Database}

The content in the resource base was used for the development and teaching of various courses in the different universities. Two types of courses were involved: those that used the content (e.g., courses on intercultural communical, photo analysis and archives) and those that dealt with the production of information resources, using the service as an example (e.g., courses in multimedia, data formats and knowledge representation. 
Most of the students (about 90\%) could find images useful for their task by using "Search" (only about $10 \%$ gave a negative answer) and about $67 \%$ of the respondents through using the "Browse galleries" option. Observation of the students showed that they were spending rather a long time looking for suitable images and performed several searches before selecting the pictures for their task. In most cases students said that the "pictures found were too old to be useful and interesting for us". In some cases "there were too few results and finding takes too much time".

For the question about usefulness of images about $71 \%$ of the respondent found them very useful and appropriate, but the remainder were not satisfied. They identified problems in finding the appropriate pictures, copying and printing the pictures, the lack of relevant pictures, the lack of information about database content, too large watermarks (adopted for intellectual property purposes), and other factors. Students also suggested that the service may be useful for their project and research work, like writing their Masters' theses.

The teachers were asked to perform searches on chosen subjects or topics and evaluate their findings. The teachers were asked to give examples of their search. The content available seemed to be of very limited use, depending upon the area of teaching. At the meta-level of interests, on the other hand, the available content proved to be very useful, e.g., for researchers in the area of knowledge organization, Web usability engineering, and science communication. Teachers of courses on cultural heritage topics were quite positive about the potential usefulness provided that much more cultural content was available and provided that multi-media content, i.e., not only images but also related texts and other media object, could be incorporated.

\section{Search Possibilities, Indexing, and Description Quality}

The intention of this issue of evaluation was directed at the user's perception of performance and, in particular, matters of search capabilities, image indexing, description quality, response speed and overall satisfaction. These issues were explored through formal interviews with the users, as they were engaged in search activity, so their activity was observed and reported. In addition, teachers of information retrieval were asked to assess the indexing quality, descriptions of images and related features separately from the professional point of view.

- Search capabilities. Most students were rather experienced in searching and easily grasped the provided possibilities. They quickly found out that there were no Boolean search or truncation features. When students located the image, most of them read the description and keywords - about $65 \%$. About $53 \%$ out of those that answered that they read the description and keywords stated that they then used terms they found in subsequent searches, while $47 \%$ did not. About $79 \%$ pointed that it was useful to do so. About $46 \%$ of the respondents preferred searching the pictures; $44 \%$ chose browsing, and $10 \%$ were in favour of combination of both techniques. In general, the search possibilities offered were sufficient for the students needs. 111 students evaluated them positively and only 29 said that search possibilities were inadequate.

- Description quality. The description quality in general was regarded as reasonable. In some cases students characterised also descriptions of images as "rather poor" or "uninformative". In general they wished more and better information about the images, better descriptions, more information about the period, the photographer, more precision in defining the location etc. One student from Katholieke Universiteit Leuven thought that more information ought to be provided for images of paintings:

"Searching for three renaissance paintings, I didn't know where to fill in the term 'Renaissance'. I tried it in the different boxes in the advance search option but I only found a few paintings and where the word 'Renaissance' was in the description of the painting. I could not know for sure that the found paintings were Renaissance paintings because the 
description only said, for instance, that the people on the painting are wearing 'Renaissance clothing'. When I searched for certain Renaissance painters I found a lot of useful images, but of course this only works if you know Renaissance painters or if you use another search engine like Google."

This illustrates the problems not only in the description of images but also in the search engine. These problems were highlighted by the responses from teachers and course designers; those from the Jagellonian and Vienna Universities found the descriptions acceptable, but those from the other pilot sites found them very lacking; e.g., teachers of information systems and retrieval said that indexing is "not understandable. Where do the list of the words come from? Some very complex descriptions, some have plenty of terms, some have next to nothing."

- Response speed: The response speed was rather slow when more results were found, but the observation showed that, in general, it was adequate. The students noted that browsing took more time to get the results, while searching in general got faster results. The same results were reported by the teachers.

- Satisfaction: The overall satisfaction with search possibilities and descriptions was rather low among both students and teachers. Poor indexing and unstructured descriptions as well as inadequate search possibilities were irritants.

\section{Presentation of Results and Quality of Images}

- Presentation of results. It seems that for the students the criterion of result presentation was not important. They did not question the order of the presentation and when asked they explained that it does not matter; generally, they got very few relevant hits and it is easy to go through all pictures.

- Quality of images. In general, the quality of the images was rated as acceptable and high$55 \%$ of students rated them of reasonable quality for my purposes, and $40 \%$ as high quality images. They expressed the wish to have newer and more up-to-date images and a greater variety of them. Some also suggested that pictures were "dull" and "too dark" and one student explained that this database would not be attractive to young users as they are used to "bright technicolour quality".

\section{Interface and Navigation}

- Ease of learning. In general students and teachers did not find it difficult to learn how to use the EURIDICE service; they found it rather easy. Fifty percent of students marked the service as Easy or Very Easy to learn and only 7\% marked it as Very Difficult. Most of the students (19) thought that they became comfortable with the service in several hours, two in a day and one (who thought it is very difficult to learn) needed several days. The latter said also that the time for learning was significantly reduced when working with a tutor. This corresponds with the observation data. Most of the students understood the general features and started using the system immediately after or during the first training session. About $69 \%$ of the respondents took a couple of hours to feel comfortable in using the service. Only $15 \%$ said that it took them one day and $12 \%$ said it took several days. However, most of them were using the simplest features of the system and some of them were finding new possibilities even during the examination session or were searching for ways to perform what they wanted: how to access the galleries, how to get back to the thumbnail views after viewing one of the images, etc. 
- Navigation. The observation data shows that students tried to use the common Internet browser features (e.g., back button) or standard features that they were used to in other databases (e.g., getting next picture from the gallery after viewing one) and these did not work in the EURIDICE service. One of the students noted that, "There are circling motions (bugs), very annoying if the database is used longer". Teachers experienced similar problems, and particularly noted the lack of an in-built 'Help' function: this information was available in printed material on the system but not in the system itself.

\section{Use of the Resource for E-Learning}

This particular aspect of evaluation concerns mainly teachers developing e-learning courses or materials. This issue was addressed by observing the process of training of the teachers and their work with the EURIDICE service. The questions to the teachers also addressed the issue of the general effectiveness of the image use in the study process and the improvements to the service that would enhance the usefulness of the service and will make it more attractive.

Results on these issues were not so positive. Most of the respondents gave a negative answer arguing that the technology offered should be improved and up to date, above all the aspects of content and interface (possibilities of integration of different technological systems) were regarded as problematic. The teachers indicated that the number of images in the database is too small (does not reach a critical mass) and there is free availability of images from elsewhere and pointed out the need to develop search possibilities. In general they do not see that it is useful enough and developed to the point that would justify the expenditure of immediate acquisition by their institutions. One sees it as a commercial venture that is too expensive for an educational institution.

\section{Evaluation from the Perspective of Blind and Visually-Impaired Users}

All participants from e-ISOTIS were extremely positive about the possibility of learning online, while also being able to access related information and data (images). They also expressed interest in using the platform for new training courses, using its functionalities.

Overall, all participants were enthusiastic about the possibilities offered by the EURIDICE elearning environment and were eager to use this again in future for other courses. Especially the involved teacher - who is also vision impaired - was extremely positive about the opportunities offered through e-learning. In this respect also, she was eager to teach her current courses with the platform, as long as, of course, all accessibility issues were properly addressed.

e-ISOTIS has also examined another accessible e-learning platform (ATutor), where the EURIDICE image repository could be easily integrated. Initial testing indicates that almost all accessibility problems are overcome with this open source initiative.

In general, the EURIDICE concept was positively received by all the participants, especially because it gave them the opportunity to easily access course material and look for related pictures without having to search through other channels. A barrier, however, was the accessibility problems located in the core e-learning platform MOODLE, as well as in the magnifying functionality developed by Alinari. However, these problems can be easily addressed and do not require a major change, but rather fine-tuning of code.

\section{Conclusions}

At present, the EURIDICE service requires significant improvements to be accepted and capable to satisfy users' needs in terms of usability of the search/retrieval tools; completeness of the offered resources, indexing and description quality. 
The assessment has shown neither the process of retrieval and usage of images from the EURIDICE service (efficiency), nor the relevance of the service and also the effectiveness (outcome) of its usage is sufficient for the intended customers and end users for e-learning purposes. On the other hand, the interest of users and general evaluation process allows us to state that basically the system is received well and seen as a sound potential for e-learning even if it needs some further improvements. The validation phase has provided a set of recommendations that should be implemented to meet the needs of the segment of the market and to be competitive in many respects. The recommendations mainly confirm what has been found by Choi and Rasmussen (2002): the topicality (content) of images is the most important for searching, therefore the elements in image description play a very important role in using EURIDICE service as a learning object.

The EURIDICE service was found to be relevant to the end users in general terms, but requires substantial improvements of all features to cater to their specific needs.

The major issue of attractiveness of the service to the market requires that the whole network of content providers should be expanded in order to offer much more content than at the moment in order to significantly increase the usefulness and relevance of the project to potential customers. The close attention to the enhancement of the retrieval features is also crucial to increase the attractiveness to the end users. From a research perspective the work done so far in the project is seen as positive. The business models with the educational customers suggested by some of the partners in the local reports may be suitable only within the framework of the project consortium and do not satisfy the long term business requirements. The business success depends on the future organization and deployment in terms of providing the EURIDICE service to many institutions and use of a variety of business models.

\section{Acknowledgements}

We would like to thank all of the EURIDICE partners for their participation in the evaluation process and our research assistants Pieta Eklund and Maria Lindh for their contribution to the work carried out at the University College of Boras. We are also indebted to the anonymous referees for their helpful comments on the original draft of this paper.

\section{References}

Beck, R. J. (2007). Learning objects. Retrieved 3 December, 2007 from http://www.uwm.edu/Dept/CIE/AOP/learningobjects.html

Besser, H. (1999). Network access to visual information: A study of costs and uses In IFLA Council and General Conference. 65th Conference programme and proceedings, Bangkok, Thailand, 1999. Retrieved 2006-10-06 from: www.ifla.org/IV/ifla65/papers/021-112e.htm

Choi, Y., \& Rasmussen, E.M. (2002). Users' relevance criteria in image retrieval in American history. Information Processing and Management, 38(5), 695-726.

Duval, E., \& Hodgins, W. (2004). Learning objects revisited. In R. McGreal (Ed.). Online education using learning objects (pp. 71-82). London: Routledge.

Friesen, N. (2004). Three objections to learning objects. In R. McGreal (Ed.). Online education using learning objects (pp. 59-70). London: Routledge.

Institute of Electrical and Electronics Engineers. Learning Technology Standards Committee. (2002) IEEE Standard for Learning Object Metadata. New York, NY: Institute of Electrical and Electronics Engineers. (IEEE Standard 1484.12.1 - draft) Retrieved 4 December, 2007 from:

http://ltsc.ieee.org/wg12/files/LOM_1484_12_1_v1_Final_Draft.pdf 
Lecher, M. (2004). Technophobes teaching with technology. In Proceedings of the 2004 ASCUE Conference. Myrtle Beach (South Carolina), 2004. Retrieved 4 December, 2007 from:

http://fits.depauw.edu/ascue/Proceedings/2004/p171.pdf

McGreal, R. (Ed.). (2004). Online education using learning objects. London: Routledge.

Mowat, E. (2002). Teaching and learning with images, VINE, 32(3), 5-13.

Standford, P. (2002) Digital images in education: on overview, VINE, 32(3), 2-4.

\section{Appendix}

\begin{tabular}{|c|c|c|c|c|}
\hline \multicolumn{5}{|c|}{ Students at the main pilot sites } \\
\hline Pilot site & $\begin{array}{c}\text { User } \\
\text { groups } \\
\text { (students) }\end{array}$ & $\begin{array}{l}\text { Courses } \\
\text { attended }\end{array}$ & $\begin{array}{l}\text { ICT Confidence and } \\
\text { Skills (average on a } \\
\text { scale of } 0 \text { to } 5 \text { ) }\end{array}$ & Main characteristics \\
\hline $\begin{array}{l}\text { University } \\
\text { College of } \\
\text { Borås }\end{array}$ & 23 & $\begin{array}{l}\text { International } \\
\text { and } \\
\text { intercultural } \\
\text { communication }\end{array}$ & $\begin{array}{l}3,85 \text { - The highest confi- } \\
\text { dence is felt in using } \\
\text { communication pro- } \\
\text { grammes like e-mail } \\
(4,54) \text {, using the Internet } \\
(4,35) \text {, in general com- } \\
\text { puter management }(4,34) \text {, } \\
\text { and word processing } \\
(4,24) \text {. The lowest confi- } \\
\text { dence and skill level con- } \\
\text { cerns usage of database } \\
\text { creation software }(2,74) \text {. }\end{array}$ & $\begin{array}{l}\text { Most of the students ( } 16) \text { fell } \\
\text { into the age category from } 21 \text { to } \\
25 \text { years. Three were } 26-30 \text { and } \\
\text { three were more than } 30 \text { years } \\
\text { old. } \\
\text { Six students were in the second } \\
\text { year of the studies, ten in the } \\
\text { third, four in the fourth year, and } \\
\text { two were mature students in the } \\
\text { fifth and sixth year of the study. }\end{array}$ \\
\hline $\begin{array}{l}\text { University } \\
\text { of Krakow }\end{array}$ & 140 & $\begin{array}{l}\text { Information } \\
\text { sources, } \\
\text { Electronic } \\
\text { journals, } \\
\text { Multimedia, } \\
\text { Data formats, } \\
\text { Content } \\
\text { characteristics } \\
\text { of documents }\end{array}$ & $\begin{array}{l}3.95 \text { - The highest abili- } \\
\text { ties in taking communi- } \\
\text { cations programs, so like } \\
\text { general using the com- } \\
\text { puter ( } 4.55) \text {, for process- } \\
\text { ing texts (4.52), for tak- } \\
\text { ing the Internet (4.33) } \\
\text { and email ( } 4.29) \text {. The } \\
\text { littlest abilities and dem- } \\
\text { onstrated experience } \\
\text { stayed in the scope of } \\
\text { providing software for } \\
\text { creating databases (2.88). }\end{array}$ & $\begin{array}{l}\text { Most of the students ( } 76 \text { ) fell } \\
\text { into the age category from } 21 \text { to } \\
25 \text { years. } 36 \text { students were in the } \\
\text { age of } 17-20,13 \text { students were } \\
26-30 \text { and } 15 \text { were more than } 30 \\
\text { years old. } \\
\text { Students were in the first, second } \\
\text { year of the studies, fourth year, } \\
\text { and in the fifth year of the study } \\
\text { (SUMIK). }\end{array}$ \\
\hline $\begin{array}{l}\text { University } \\
\text { of Leuven }\end{array}$ & 20 & $\begin{array}{l}\text { Notes on Photo } \\
\text { Analysis. How } \\
\text { to read a pho- } \\
\text { tographic im- } \\
\text { age? }\end{array}$ & $\begin{array}{l}\text { All students are trained in } \\
\text { using office software and } \\
\text { Web technologies. They } \\
\text { can be considered to be } \\
\text { proficient ICT users. }\end{array}$ & $\begin{array}{l}16 \text { students were post-graduate } \\
\text { students, in their 3rd to } 4 \text { th year } \\
\text { of study. } 8 \text { of them are studying } \\
\text { Modern History. } 6 \text { were studying } \\
\text { for a master after master degree } \\
\text { at the Institute for Cultural Stud- } \\
\text { ies, this means they are in their } \\
5 \text { th year of university studies. }\end{array}$ \\
\hline
\end{tabular}




\begin{tabular}{|c|c|c|c|c|}
\hline \multicolumn{5}{|c|}{ Students at the main pilot sites } \\
\hline Pilot site & $\begin{array}{c}\begin{array}{c}\text { User } \\
\text { groups } \\
\text { (students) }\end{array} \\
\end{array}$ & $\begin{array}{l}\text { Courses } \\
\text { attended }\end{array}$ & $\begin{array}{l}\text { ICT Confidence and } \\
\text { Skills (average on a } \\
\text { scale of } 0 \text { to 5) }\end{array}$ & Main characteristics \\
\hline $\begin{array}{l}\text { University } \\
\text { of Vienna }\end{array}$ & 34 & $\begin{array}{l}\text { Seminar: "Wis- } \\
\text { sensrepräsen- } \\
\text { tation" } \\
\text { Knowledge } \\
\text { representation }\end{array}$ & $\begin{array}{l}\text { High as a result of the } \\
\text { studied programmes }\end{array}$ & $\begin{array}{l}\text { Mainly PhD students but also } \\
\text { MA students with a real interest } \\
\text { in issues of knowledge represen- } \\
\text { tation, eLearning, science com- } \\
\text { munication, information visuali- } \\
\text { zation, usability engineering, } \\
\text { ontology engineering, pedagogy, } \\
\text { history of art and science, theory } \\
\text { of art, philosophy of science, } \\
\text { information science. }\end{array}$ \\
\hline $\begin{array}{l}\text { Virtual } \\
\text { University } \\
\text { of } \\
\text { Barcelona }\end{array}$ & $8 *$ & $\begin{array}{l}\text { Internet Search } \\
\text { Course }\end{array}$ & $\begin{array}{l}4,3 \text { in general computer } \\
\text { competence }(4,6 \text { in com- } \\
\text { munication programmes, } \\
4,4 \text { in using Intenet and } \\
\text { lowest averages for } \\
\text { spreadsheet use and data- } \\
\text { bases) }\end{array}$ & $\begin{array}{l}\text { All students of the Barcelona } \\
\text { Virtual University, part of a } \\
\text { course of distance learning with } \\
\text { the Barcelona Virtual University } \\
\text { to complete their public univer- } \\
\text { sity studies. The } 8 \text { participants } \\
\text { are enrolled in superior univer- } \\
\text { sity studies. } \\
\text { The average age of the sample is } \\
27 \text { (26.9), with the typical devia- } \\
\text { tion of } 6.2 \text {, which represents that } \\
\text { the sample encompasses ages } \\
\text { from } 20 \text { to } 32 \text {. }\end{array}$ \\
\hline
\end{tabular}

\section{Biographies}

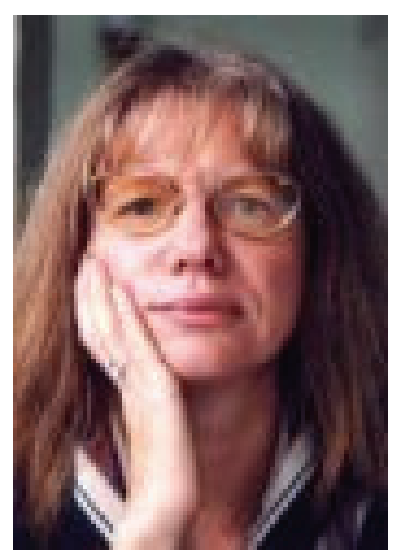

Elena Maceviciute is Senior Lecturer (docent) in the Swedish School of Librarianship and Information Science at the University of Gothenburg and the University College of Boras. Her research interests are in information management and bibliography and reference work. She is also Professor in the Faculty of Communication, University of Vilnius, Lithuania. 


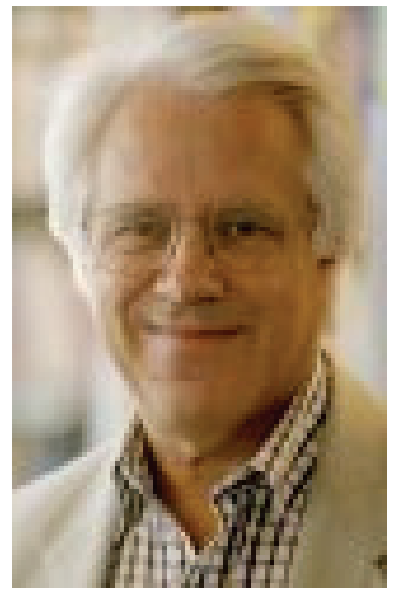

Tom Wilson is Professor Emeritus, University of Sheffield, UK and Visiting Professor, in the Swedish School of Librarianship and Information Science. He is also Visiting Professor, Leeds University Business School, where he is Associate Director of the AIMTech Research Group and Professor Catedratico Convidado in the Faculdade de Engenheria, Universidade do Porto, Portugal. In 2005 he was awarded an Honorary PhD (Hedersdoktor) by the University of Gothenburg. He has research interests in information behaviour, information management and mobile information systems. He is Publisher and Editor-inChief of Information Research, an open access scholarly journal. 